University at Buffalo School of Law

Digital Commons @ University at Buffalo School of Law

$10-27-2016$

\title{
Africans and the ICC: Hypocrisy, Impunity, and Perversion
}

Makau wa Mutua

University at Buffalo School of Law, mutua@buffalo.edu

Follow this and additional works at: https://digitalcommons.law.buffalo.edu/book_sections

Part of the Criminal Law Commons, and the International Law Commons

\section{Recommended Citation}

Makau W. Mutua, Africans and the ICC: Hypocrisy, Impunity, and Perversion in Africa and the ICC:

Perceptions of Justice 47 (Kamari M. Clarke, Abel S. Knottnerus, \& Eefje de Volder, eds., Cambridge

University Press 2016)

This material has been published in Africa and the ICC: Perceptions of Justice edited by Kamari M. Clarke, Abel S. Knottnerus, \& Eefje de Volder. This version is free to view and download for personal use only. Not for redistribution, re-sale or use in derivative works. (c) Cambridge University Press 2016.

\section{IN COPYRIGHT}

This Book is brought to you for free and open access by the Faculty Scholarship at Digital Commons @ University at Buffalo School of Law. It has been accepted for inclusion in Contributions to Books by an authorized administrator of Digital Commons @ University at Buffalo School of Law. For more information, please contact lawscholar@buffalo.edu. 


\section{Africans and the ICC Hypocrisy, Impunity, and Perversion}

Makau W. Mutua

\section{INTRODUCTION}

Contemporary discussions of the International Criminal Court (ICC) and Africa are characterized by intellectual disagreement and political passion. There is a rich diversity of perspectives, many of them open to contestation. But the location and identity of the speaker, or author, are critical. So is the place of history and the relationship between the post-colonial African state and the struggle for human dignity. The subject is complicated by Africa's tortured place in geopolitics. However, the pain of history - and its echo in Africa - must not be used to sabotage the cry of victims for justice. There is no doubt that a conversation about the legitimacy of the ICC in Africa in view of the deeply emotional and historical issues raised by the African Union is a matter that has preoccupied political elites, civil society, and intellectuals on the continent, hence the title (and sub-title) of this chapter. Shamiso Mbizvo of the Office of the Prosecutor engages the ICC's critics on this debate in her speech published here (see Chapter 2). While I welcome the OTP's response to its sceptics, I believe it should go further and acknowledge the heavy focus on African perpetrators to the exclusion of others. In my view, the ICC will not be able to blunt the charges of a racist agenda if it cannot produce indictments of senior officials from continents other than Africa. It will not suffice to promise investigations outside Africa. ICC Chief Prosecutor Fatou Bensouda must aggressively pursue perpetrators without regard to station, race, identity, and national origin for the ICC to be seen to do justice without fear, favour, or prejudice.

The title of my chapter directly wades into this charged debate and recalls, ironically, the charge that the "ICC is hunting Africans". I want to make clear that this is not hyperbole, but an actual statement made by the prime minister 
of Ethiopia - Hailemariam Desalegn - as chair of the African Union. Presumably, he was speaking for the African Union. ${ }^{2}$ Desalegn's calculated use of the phrase "hunting Africans" is, needless to say, both evocative and deeply disturbing because it conjures up - indeed dredges up - the most unspeakable images and memories of the subordination of Africans by white Europeans and the West. How did the ICC, a court that was built to deal with those same unspeakable crimes, come to be accused of committing them? This is but one of many ironies inherent in this conversation.

That is why the subtext - perhaps the actual text - of this conversation is not possible without stipulating a few historical truths and narratives about international law and the Third World, and in this case Africa in particular. It is true that what one considers a historical truth might be contested, but those biases are unavoidable. History is clear that no other continent has suffered more trauma than Africa over the past 500 years. Much of that trauma has been inflicted on Africa by the North Atlantic communities - Europe and the United States. The Arab slave trade was equally damaging. The plunder and theft of Africa's resources for the benefit of the West cannot be gainsaid. It was thought independence from European colonialism would bring relief to a beleaguered continent. The cauldron of the Cold War and a scandalous international economic order combined to ravage the emergent African states. ${ }^{3}$ Yet those who attack the ICC seem to suffer from historical amnesia and selective memory. Their arguments want to place all the blame for the trauma of Africa on the European West. Theirs is an apology for the sins of their fathers and a hypocritical pan-Africanism by ruling elites and their ideologues. They deliberately pervert history to hoodwink ordinary Africans and play on white guilt. I reject this false historical narrative and its sinister attempt to hijack the stories of genuine pan-Africanism and the pain of victims to maintain bankrupt African elites in power.

At a minimum, African post-independent rulers must share the blame for the failure of the continent to incubate democratic states. They could not even successfully implant the liberal constitution to achieve a credibly bare republican state. The elites chose to become kleptocrats bent on first consolidating their own personal power. They stifled dissent, sheathed themselves in corrupt ethnic cocoons, dismantled liberal constitutions, and buttressed the patrimonial state. ${ }^{4}$ High corruption and crude patronage became a culture. The rule of law died. Judiciaries became proxies for executive repression. Legislatures were turned into executive rubber stamps. Infrastructures collapsed, societies fragmented, and religious, civil, and armed conflicts - many along ethnic lines - erupted and became intractable. A number of states either failed or collapsed completely. There is no doubt African elites had a lot of help from 
their Cold War allies in destroying their states. But it is revisionist history to invoke the spectre of Western domination and exploitation without taking responsibility for collaborationist African elites. Nor is the ICC an imposition on Africans by the West. There was a stampede in Africa to ratify the Rome Statute of the ICC. It was only after the Court indicted leading African kleptocrats, such as Uhuru Kenyatta of Kenya and Omar al-Bashir of Sudan, that the $\mathrm{AU}$ raised the bogeyman of racism to discredit the Court. This chapter takes issue with this perverted narrative of the ICC and the history of African marginalization by the West. Repressive African leaders grouped in the AU a club of dictators - have no moral standing to attack the ICC, an institution built through a participatory global consensus to combat impunity and bring justice which elites deny victims at home.

\section{HISTORICAL TRUTHS ABOUT INTERNATIONAL LAW}

A paradox of Africa's problems with international law is that the continent itself - by which it is meant the modern states that comprise it - is largely a creation of international law. International law treated Africa as tabula rasa, ${ }^{5}$ a blank slate on which Europe could scribble its forms of logic, hierarchies, and forms of social organization. That is to say that Africa's identity in the era of modernity has largely been shaped by its encounter with the West, the normative home of international law. ${ }^{6}$ In that sense, Africa is an "outsider" to international law ${ }^{7}$ - it is, to wit, one of the originally subordinated continents in which international law was used as a means of ordering and organizing the exploitation of the globe for the benefit of the North Atlantic communities. ${ }^{8}$ So, at the outset, scholars need to acknowledge a number of basic and unarguable historical facts.

Modern African states, themselves illegitimate creations of colonialism, ${ }^{9}$ were frozen in place by the international legal principle of uti possidetis, ${ }^{10}$ even when they were patently dysfunctional. The facts are the following: first, that modern international law was inimical to Africa's interests; ${ }^{12}$ second, that modern international law was used to cannibalize Africa's resources and people; ${ }^{12}$ third, that modern international law was used to justify the "management" of Africa as indeed all of the Third World for the hegemonic interests of North Atlantic states. ${ }^{13}$ It is not an overreach to say that international law was used to stamp Africa and Africans with sub-humanity so that they and their resources could be exploited for the benefit of others.

There really is no other way to understand the three historical traumas that define modern Africa. First, the trauma of slavery, which international law recognized, and which deeply depopulated the continent while building 
Europe and the Americas; ${ }^{24}$ second, the trauma of colonialism, which international law structured, and some say invented; ${ }^{15}$ and third, the trauma of the Cold War, in which Africa was plundered by both the East and the West and used as a pawn in proxy wars of supremacy. ${ }^{16}$ Africa is now in a fourth phase, with the legacies of the first three traumas still exerting their influence, but in the context of a resurgent Africa that is demanding more respect and equity in global affairs. ${ }^{17}$ It is because of these traumas that Africa has had an ambivalent - if not at times completely hostile - relationship with international law and international institutions, including the International Criminal Court. ${ }^{18}$ But African views of international law are not monolithic, as these sketches of the typologies of African views to international law demonstrate. However, a distinction must be made between the views of the states, and those of the African peoples, for the two are rarely congruent.

\section{TYPOLOGIES OF AFRICAN VIEWS ON INTERNATIONAL LAW}

One way to understand and characterize African views of international law is not only by segmenting them by the constituency of scholars, but particularly by historical period. First, the early African international law scholarship dealt with the colonial moment and whether, and how, Africa could enter the community of nations and leverage existing regimes, or transform them to cater to its own interests. Here, at the dawn of the Independence Decade, there was much hope and optimism in Africa and its potential. ${ }^{19}$ Mostly newly minted African states sought entry into the world community on an equal footing - exemplified most poignantly by membership in the United Nations. ${ }^{20}$ African scholars held a dichotomous view on whether or how the continent could leverage its status of juridical equality with other states. ${ }^{22}$ Many were clearly accomodationist ${ }^{22}$ - seeking to understand the system and effectively participating in it without necessarily questioning its basic norms and whether they were biased against Africa. This group sought inclusion without being critical of the normative edifice of international law - many African states adopted this view early on.

Second, another group of African scholars was highly critical of the international legal regime, and questioned its ability for fairness - scholars like Professor Issa Shivji of Tanzania or jurists like Mohamed Bedjaoui of the International Court of Justice come to mind. ${ }^{23}$ But as African states experienced structural and normative barriers to entry into the global system, ${ }^{24}$ the tone of the continent's scholars turned increasingly critical of international law. These problems were exacerbated by regime instability and state decay through coups usually backed by the West or East ${ }^{25}$ and economic stagnation 
in spite of enormous natural resources. African states and elites could not cohere into nation-states because of economic inequities, ethnic divisions, and elite dissensus. In other words, the optimism of the early independence period evaporated sooner than one might have expected, in part due to the inability of the African post-colonial state, itself an artificial creature, to cohere into a nation amidst a hostile international system. These protest scholars, many of them with a leftist ideological hue, spawned a new generation of critical thinkers. That is why they - and African states - turned into dialogues focused on South-South Cooperation and the New International Economic Order. ${ }^{26}$ But political efforts for a more equitable international order were blunted by the West and the re-assertion of the primacy of the Bretton Woods institutions in African states through structural adjustment programs and other neo-conservative and neo-liberal markets measures.

Third, in the late 1970 s to the 1990s, African international legal scholars many of them with intellectual roots on the political left - increasingly turned to the equal protection language of the human rights project. This was partly a response to the collapse of the Soviet and Socialist models as alternatives. Some, like Justice Keba Mbaye of the International Court of Justice, tried to imbue human rights with an African fingerprint. ${ }^{27}$ Many sought to use human rights as a language to disrupt neo-colonial abusive regimes still in cahoots with international capital and their Western sponsors. Their focus was - and has been - to rewrite the internal charters of African states and African regional bodies. ${ }^{28}$ The idea was to reconstitute the fabric of the state by deploying home-grown liberal norms and through African institutions. These scholars now focus on questions of regional economic integration, technology innovation, gender equality, international criminal law (ICC, Rwanda, Sierra Leone), and local intellectual entrepreneurship. ${ }^{29}$ It is this school of thought that has been responsible for the democratic renaissance in Africa over the last two decades. But they have not reaped the benefits of their aspirations. These progressive elites helped overthrow the corrupt and dictatorial one-party states, only to see power captured by established political elites from the old order. ${ }^{3 \circ}$ The bottom line is that most states in Africa have adopted the forms and processes of democratic government, but the practices of governance are either still autocratic in culture, or subject to manipulation by vested political elites. The point is that various African state actors today pursue duplicitous and hypocritical views of international law. Some speak the language of human rights and democracy when it is convenient, but use hypocritical arguments when they need to protect the interests of illegal cabals that control the states. For example, Kenyatta, whose case for crimes against humanity at the ICC was suspended in 2014 for lack of sufficient evidence amid claims of 
witness tampering, often attacked the ICC as a colonial court even as he shielded himself and other suspects of heinous crimes from justice. ${ }^{31}$ In what is interpreted as a culture of impunity, Kenya refused to prosecute other suspects, claiming lack of evidence. ${ }^{32}$ In other acts of subterfuge by African leaders, the AU have attempted to establish an African Court of Justice and Human Rights to try heinous offenders to render the ICC unnecessary. ${ }^{33}$ These are attempts to sabotage the ICC by establishing a toothless body. One might call African leaders pragmatic - they will use international law where and when it benefits elites and even the states, but clearly oppose it where it seeks to curb the power and authority of ruling political elites.

\section{THE RATIONALE OF THE ICC}

The International Criminal Court was created to deal with impunity by bringing to account those who commit the most heinous crimes - war crimes, crimes against humanity, genocide, ${ }^{34}$ and, in 2017 , crimes of aggression. ${ }^{35}$ The creation of the court culminated a decades-old struggle to create a permanent international criminal tribunal..$^{6}$ It is a court of last resort a complementary court - which acts only when states are unable, or unwilling, to prosecute offenders. ${ }^{37}$ To date, the Rome Statute has been ratified by 123 states, and this includes all of South America, most of Europe, most of Oceania, and thirty-four African states - or two-thirds of all African countries. ${ }^{38}$ Three states - the United States, Israel, and Sudan - unsigned the Rome Statute without ratifying it. ${ }^{39}$ Russia has signed, but not ratified the Rome Statute..$^{40}$ Forty-one states, including India and China, are not signatories and are openly critical of the Court..$^{41}$ The United States was deeply hostile to the ICC under George W. Bush, ${ }^{42}$ but has reversed course and is seen as helpful to the ICC's work under President Barack Obama. ${ }^{43}$

\section{AFRICA AND THE ICC}

Many African states and NGOs were early and enthusiastic supporters of the ICC. ${ }^{44}$ In fact, contrary to the traditional script of international law in which Africa is seen as an afterthought, and a consumer of ideas, as opposed to a producer of thought, the continent was a central player in the birth of the ICC. ${ }^{45}$ Africa's enthusiasm about the ICC was a result of two factors: first, the large and activist civil society, mostly in human rights, that has emerged since the early $1990 \mathrm{~s}^{46}$ as the wave of democratization swept the continent; second, the political inclination of most African states emerging out of dictatorship to embrace calls to end 
impunity. ${ }^{47}$ These two factors combined to create a fertile ground for the legitimacy of the ICC in Africa. Emerging democracies in Africa during the wave of the so-called Second Liberation were keen to signal their repudiation of the culture of impunity cultivated by the preceding oneparty states and military dictatorships. That was partly the case because many post-Cold War regimes included among their leaders prominent civil society actors and pro-democracy advocates. In fact, the African bloc of thirty-four States Parties constitutes the largest contingent at the ICC. $4^{8}$

\section{THE ICC'S INVESTIGATIONS AND CASES}

To date, the ICC has opened twenty-one cases in nine "situations" or countries, all of which have been in Africa (DRC, Kenya, Libya, Sudan, CAR, Mali, Cote d'Ivoire, and Uganda) ${ }^{49}$ Of these nine, five were self-referrals by the states concerned (Uganda, DRC, CAR, Mali, and again the CAR). Two cases (Libya and Sudan) were referred to the Court by the UN Security Council. Two others (Kenya and Cote d'Ivoire) were started by the Prosecutor proprio motu, or on his own initiative. For its part, Kenya had agreed pursuant to a peace accord brokered by former UN Secretary-General Kofi Annan to end the 2007-2008 near-genocidal violence that Kofi Annan would hand over an envelope containing the names of suspects from a government commission of inquiry to the ICC for investigation and prosecution if Kenya failed or was unwilling to prosecute them. Kenya refused to establish a local tribunal, thereby triggering the ICC's investigation..$^{\circ 0}$ So, in a sense Kenya's case could be viewed as a quasi-self-referral. The case of Cote d'Ivoire, involving the deposed President Laurent Gbagbo and his wife, was urged on the ICC by the African Union. ${ }^{51}$

\section{CONFLICT BETWEEN THE AFRICAN UNION AND THE ICC}

The first signs of conflict between the African Union and the ICC occurred when the ICC indicted and charged President Omar al-Bashir of Sudan and several high-ranking officials for the pillage of Darfur..$^{52} \mathrm{Al}$-Bashir mobilized support from the African Union and some Arab states, ${ }^{53}$ although the support he received was quite tepid - in fact, some African states including Botswana, South Africa, Malawi, and Uganda threatened to arrest him and hand him over to the ICC should he set foot on their soil. ${ }^{44}$ Even among the AU heads of state, who jealously protect their own from justice and are defined by the impunity with which they act, al-Bashir was difficult to openly protect because of the Darfur situation. 
The second instance of conflict occurred when the UN Security acted with stunning speed to refer Muamar Gaddafi and his associates to the ICC and the Court acted immediately to take up the case. ${ }^{55}$ Africa was incensed over the Libyan situation because it was largely viewed as an act of hegemonic powers using the Court to get rid of an old enemy by disregarding the pleas of the $\mathrm{AU}$ to mediate the conflict. ${ }^{56}$ Many African states felt that the ICC was being used to fight the wars of the West against an African leader. The resolution to refer Libya to the ICC was unanimously adopted with the African states sitting as Security Council (SC) members (South Africa, Nigeria, and Gabon). ${ }^{57}$ The African states wanted the SC to send a clear message to Libya to end the carnage.

Third, it was in this climate that the Court proceeded to open the trials of Uhuru Kenyatta and William Ruto,,$^{8}$ who had mobilized their supporters to elect them in March 2013 as president and deputy president knowing that they were ICC indictees. ${ }^{59}$ Kenya is an influential regional power in Africa, a strategic partner to the West on the war against terrorism, and a gateway to stability and humanitarian missions in East Africa. It has a sophisticated political elite and large business and middle classes. Kenyatta has exploited all of these diplomatic, social, economic, and political assets in a bid to get the cases dropped altogether, or deferred by the UN Security Council (under Article 16 of the Statute). ${ }^{60}$ The UN Security Council rightly rejected a joint AU/Kenya request for a deferral late 2013. ${ }^{61}$ However, on 5 December 2014, ICC Prosecutor Fatou Bensouda withdrew the charges against Kenyatta, citing a lack of sufficient evidence because of the failure of the Kenyan state to cooperate with the Court by providing it with information required by the prosecution. ${ }^{62}$ On 20 January 2015 , Bensouda released the entire sixty-ninepage pre-trial brief on Kenyatta. ${ }^{\sigma_{3}}$ The document, which she would have used against Kenyatta had the case gone to trial, is an explosive and damning account of charges against Kenyatta and his associates. It details how Kenyatta planned and financed the Mungiki, a deadly Kikuyu tribal militia, to commit crimes against humanity. Perhaps most chillingly, the legal brief documents specific cases of the murder, bribery, and intimidation of scores of witnesses. It leaves little to the imagination. The logical conclusion from the brief is that Kenyatta had to kill the witnesses, in what the prosecution termed a "clean up" operation to avoid a conviction.

But even before his case was withdrawn, though not terminated, Kenyatta had succeeded where al-Bashir failed - he managed to unite the entire AU in endorsing a call for a deferral, or complete stoppage of the cases. ${ }^{64}$ The AU voted in October 2013 that Kenyatta should not show up for his trial at The Hague in a "colonial white man's court" ${ }_{5}$ that is a "tool of Western 
powers". ${ }^{66} \mathrm{Mr}$. Kenyatta himself, in an address to the AU, said this: "The ICC has become a farcical pantomime, a travesty that adds insult to the injury of victims. It stopped being the home of justice the day it became the toy of declining imperial powers" ${ }^{67} \mathrm{He}$ asked the AU leaders gathered to be wary of "persistent machinations by the West". 68

The ICC has been brought under tremendous pressure by the AU, and even some of the UN Security Council permanent members to "show flexibility"69 - perhaps allowing the indictees to skip most Court sessions, or trying them through a video link. The provision of "trial by Skype" - as mocked by critics - showed how beleaguered the ICC was. ${ }^{70}$ Kenya and the $\mathrm{AU}$ went further and pushed for amendments to the Statute to exempt sitting heads of state from the court's jurisdiction, ${ }^{71}$ which would have stricken a blow against the object and purpose of the treaty. Fortunately, this attempt at neutering the court failed. But at the Twelfth Session of the Assembly of States Parties to the Rome Statute of the International Criminal Court (ASP), which concluded on 28 November 2013 , the ASP adopted several new rules and amendments to its Rules of Procedure and Evidence. ${ }^{7^{2}}$ The core of the amendments were the use of video technology, excusal from presence at trial, and excusal from presence at trial due to extraordinary public duties. ${ }^{73}$ These amendments deeply politicized the ICC and left no doubt that it is responsive to political pressure and can be bent to the will of powerful leaders, even if they are indictees. It is a blow against the principle of equality before the law and a terrible indictment of the commitment of the Assembly of States to fight impunity. Even so, a deferral would have most likely posed an existential threat to the Court.

\section{CONCLUSION}

It is undeniable that the ICC faces a challenge to its legitimacy if all its cases continue to be African - the appearance of selective, race-based justice will be difficult to avoid if the ICC does not vigorously pursue egregious offenders elsewhere. To her credit, Bensouda has opened preliminary investigations into several situations outside Africa - Palestine, Syria, Afghanistan, Colombia, Ukraine, Honduras, and Iraq. Time will tell whether these investigations will mature into full-fledged cases. But while the charge of selectivity is persuasive, it does not vitiate the need to pursue African heads of state who have been indicted - the failure to prosecute all of the suspects does not mean that some of the suspects should not be prosecuted. This is especially true because the $\mathrm{AU}$ itself seeks to do the same thing that it is accusing the ICC of doing - it does not mind selectively exempting certain African heads of state from its 
grip, nor does it oppose the ICC trying ordinary Africans. The AU's concern is only for heads of state. In fact, the Kenya government and the AU did not seek a deferral for the case facing the third accused Kenyan - journalist Joshua Sang. ${ }^{74}$ Most tellingly - and underscoring the hypocrisy of the AU and some of its leaders, such as Yoweri Museveni of Uganda who has called on Africa to pull out of the ICC en masse - he and the AU agreed to and did hand over Dominic Ongwen of Uganda's Lord's Resistance Army to the ICC for trial. ${ }^{75}$ This conduct is both duplicitous and hypocritical. The AU viciously attacks the ICC as an evil imperialist instrumentality when it targets ruling elites, such as Kenyatta, but becomes a legitimate court to which the AU hands over rebels, such as Ongwen, for trial. There is no principle at stake here except a protection racket among African rulers within the AU.

The $\mathrm{AU}$ is not always on the same page as ordinary Africans. To drive this point home, the leading opinion pollster in Kenya showed in 2013 that $67 \%$ of all Kenyans wanted Kenyatta and Ruto be tried at The Hague. ${ }^{76}$ This divergence is startling and worthy of note. African states clearly feel bitter about the ICC, but the African publics hold a different view. The AU's position is hypocritical and only intended to shield from justice the wealthy and the powerful by demagoguing powerful and legitimate arguments about the inequity of international law. Africans have legitimate claims against international law, but attacking the ICC through race baiting because it seeks to hold accountable African heads of state is illegitimate. Kenyatta and his AU counterparts are the wrong Africans to charge the ICC and international law with targeting Africans. How can leaders whose hands are bloodyif we are to believe the ICC charges against Kenyatta, al-Bashir, Ruto, and other African leaders - manipulate legitimate African grievances against international law to defeat justice? These leaders know that there is no one else to whom they will answer if the ICC does not do its job. Their attacks on the ICC are nothing short of an affirmation of impunity with which they govern. It is important for the ICC to end the perception of selectivity and race-based prosecutions. But those indicted should not find cover and succour in race-based arguments.

Notes

1. 'African Union Accuses ICC of "Hunting" Africans', BBC News, 27 May 2013.

2. Ibid.

3. Mohammed Bedjaoui, Towards a New International Economic Order (New York: Holmes and Meijer Publishers, 1979). 
4. See, for example, Makau W. Mutua, 'Kenya's Quest for Democracy: Taming Leviathan' in John W. Harbeson and Donald Rothchild (eds.), Africa in World Politics: Reforming Political Order, $4^{\text {th }}$ edn (Colorado: Westview, 2008).

5. Tiyanjana Maluwa, International Law in Post-Colonial Africa (Leiden: Brill-Nijhoff Publishers, 1999), p. 69.

6. Antony Anghie, 'Africa, Sovereignty and International Law', Think Africa Press, 2 November 2012.

7. Makau W. Mutua, 'Critical Race Theory and International Law: The View of an Insider-Outsider' (2000) 45 Villanova Law Review 841.

8. Ibid., at 846 .

9. See generally Pierre Englebert, 'Pre-Colonial Institutions, Post-Colonial States, and Economic Development in Tropical Africa' (2000) 53 Political Research Quarterly 7, 13.

10. See Makau W. Mutua, 'Putting Humpty Dumpty Back Together Again: The Dilemmas of the Post-Colonial African State' (1995) 21 Brooklyn Journal of International Law 505, n.1. See generally 'Nigeria: Bakasi and the uti possidetis Principle', Daily Trust, 2 July 2012.

11. Walter Rodney, How Europe Underdeveloped Africa (Oxford: Fahamu Books, 1972).

12. Ali Mazrui, The Africans: A Triple Heritage (New York: Little, Brown, 1986).

13. Ibid.

14. Basil Davidson, Africa in History (New York: Simon \& Schuster, 1991).

15. Ibid.

16. Ira W. Zartman (ed.), Collapsed States: The Disintegration and Restoration of Legitimate Authority (London: Lynne Rienner Publishers, 1995).

17. David Leonhardt, 'Africa's Economy Is Rising. Now What Happens to Its Food?', New York Times, 22 January 2015.

18. William Eye and Beth Goldberg, 'A Critique of the Evolving US-ICC Relationship', Humanity in Action, 2012.

19. Mutua, 'Critical Race Theory and International Law'.

20. See UN Website, 'Growth in United Nations membership, 1945-Present' and 'Africa'.

21. See e.g. Nic J. Rhoodie, Conflict Resolution in South-Africa: The Quest for Accomadationist Policies in a Plural Society (Pretoria: Institute for Plural Studies, University of Pretoria, 1978).

22. Taslim O. Elias, Africa and the Development of International Law (Leiden: Martinus Nijhoff Publishers, 1988).

23. Issa G. Shivji, The Concept of Human Rights in Africa (Dakar: Codesria, 1989). 
24. Bedjaoui, Towards a New International Economic Order.

25. Elizabeth Schmidt, Foreign Intervention in Africa: From the Cold War to the War on Terror (Cambridge: Cambridge University Press, 2013).

26. Ralph I. Onwuka, The Future of Africa and the New Intemational Economic Order (London: Palgrave Macmillan, 1986).

27. See generally President Higgins, "Tribute to the Memory of Judge Kéba Mbaye' (International Court of Justice, 4 June 2007).

28. See generally Council on Foreign Relations, "The Global Human Rights Regime' (Issue Brief, 19 June 2013), p. 19.

29. See generally Mutua, 'Critical Race Theory and International Law'.

30. Ibid.

31. Emeka Mayaka-Gekara and Dave Opiyo, 'President Kenyatta's Stinging Attack on ICC and Europe', Daily Nation, 12 October 2013.

32. Ouma Wanzala, 'State Frustrated by PEV Cases', Daily Nation, 12 February 2014.

33. Jane Goin, 'Pan African Movement Roots for African Court of Justice', Capital News, 10 August 2015.

34. The Registry, 'Understanding the International Criminal Court', ICC-PIDS-BK-05-003/13.

35. Ibid.

36. Council on Foreign Relations, 'The Global Human Rights Regime'.

37. Ibid.

38. Coalition for the International Criminal Court, 'Africa (Sub-Saharan)', ICC Now.

39. Andrew Morgan, 'Non-Signatory Countries', Jurist, 20 July 2013.

40. Eye and Goldberg, "A Critique of the Evolving US-ICC Relationship'.

41. Ibid.

42. Ibid.

43. Ibid.

44. Arlette Afagbegee, 'The International Criminal Court's Relationship with Africa: An Unfair Bias?', Pambazuka News, 4 June 2014.

45. Ibid.

46. Paul Gready (ed.), Fighting for Human Rights (London: Routledge, 2004), p. 1.

47. Coalition for the ICC, 'Africa (Sub-Saharan)'.

48. Ibid.

49. See the ICC website, 'Situations and Cases', www.icc-cpi.int/pages/situa tions.aspx\#. Stephen A. Lamony, 'Is the International Criminal Court really picking on Africa?', African Arguments, 16 April 2013.

5o. Ibid.

51. Ibid. 
52. Coalition for the ICC, 'Africa (Sub-Saharan)'.

53. Ibid.

54. 'ICC Not for Africans - Say New Prosecutor', Face of Malawi, 25 May 2012.

55. UN, 'In Swift, Decisive Action, Security Council Imposes Tough Measures on Libyan Regime, Adopting Resolution 1970 in Wake of Crackdown on Protesters', SC/10187/Rev.1, 26 February 2011.

56. Afagbegee, 'The International Criminal Court's Relationship with Africa'.

57. United Nations, 'In Swift, Decisive Action, Security Council Imposes Tough Measures'.

58. Bernard Momanyi and Simon Jennings, 'Kenya Seeks Delay to ICC 'Trials', Institute for War \& Peace Reporting, 17 October 2013.

59. Ibid.

6o. Ibid.

61. Ibid.

62. OTP, 'Statement of the Prosecutor of the International Criminal Court, Fatou Bensouda, on the Withdrawal of Charges against Mr. Uhuru Muigai Kenyatta', 5 December 2014.

63. OTP, 'Public Redacted Version of "Second Updated Prosecution PreTrial Brief"', 26 August 2013, ICC-o1/o9-02/11-796-Conf-AnxA.

64. Javier Blas, 'AU to Call for Suspension of ICC Cases while Leaders Are in Power', Financial Times, 12 October 2013.

65. Makau W. Mutua, 'Why Matsanga Is a Liability to Uhuru and Ruto at the ICC', Standard Digital, 17 November 2013.

66. Pascal Fletcher and Edmund Blair, 'Insight: Kenya Cases Stir African Backlash against ICC', Reuters, 16 September 2013; Mark Doyle, 'African Union Urges ICC to Defer Uhuru Kenyatta Case', BBC News Africa, 12 October 2013.

67. Walter Menya, 'International Criminal Court Critique Haunts Uhuru', Daily Nation, 5 April 2014.

68. Ibid.

69. 'International Court Chiefs Brief UN Assembly on Progress, Challenges', UN News Centre, 31 October 2013.

70. 'Uhuru Kenyatta Insists He Can Run Government from The Hague', Kenya Today, 24 January 2013; James Mbaka, 'Kenya -ICC: Ruto Seeks Exemption from Attendance', Africa: News and Analysis, 13 January 2014.

71. Coalition for the ICC, 'Africa (Sub-Saharan)'.

72. ASP, Resolution ICC-ASP/12/Res.7, 27 November 2013.

73. Ibid.

74. Coalition for the ICC, 'Africa (Sub-Saharan)'. 
75. OTP, 'Statement of the Prosecutor of the International Criminal Court, Fatou Bensouda, following the Surrender and Transfer of Top LRA Commander Dominic Ongwen', 21 January 2015.

76. '67 per cent Want Uhuru to Attend ICC Trials - Poll', Star, 14 November 2013; Musa Haron, 'Kenyans Want Kenyatta to Attend ICC Trial', Safari Africa, 14 November 2013. 